\title{
УДК 811.161.1-3.09
}

\section{THREE MYTHS ABOUT THE "LITTLE MAN" IN THE WORKS OF THE EARLY F.M. DOSTOEVSKY \\ ТРИ МІФИ ПРО «МАЛЕНЬКУ ЛЮДИНУ» В ТВОРЧОСТІ РАННЬОГО Ф.М. ДОСТОСВСЬКОГО}

Tveritinova T.I. / Tверітінова T.I. c.ph.s., as.prof. / к.ф.н., доu. ORCID ID: 0000-0002-7731-2040

Boris Grinchenko Kyiv University, Kyiv, Tymoshenko, 13-b, 04212 Київський університет імені Бориса Грінченка, Київ, Тимошенка, 13-б, 04212

У статті розглядається один із аспектів гоголівського впливу на творчість раннього Ф. М. Достоєвського - проблема міфологізаиії «маленької людини». Мета дослідження простежити формування міфу про переписувача, про мрійника і про самозвания в творах Ф. М. Достоєвського 1840-х рр. ("Бідні люди», "Двійник», "Слабке серие», "Хазяйка», "Білі ночі»). Досліджується життя переписувачів і мрійників за агіографічним сюжетом, в який петербурзька дійсність вносить свої корективи: житіє перетворюється на антижитіє, а героїв замість святості й чудодійства очікує моральне й містичне падіння. Простежується втручання образу-химери - жінки, яка виступає в ролі демонської спокуси.

В міфі про самозвания визначається прагнення героїв втілити свої амбітні фантазії, видавши себе за іншого. Але всі варіанти протистояти петербурзькій реальності призводять героїв до катастрофи, щэо включає міфи про «маленьку людину» в більш загальний культурний міф про велике місто та його есхатологію.

Ключові слова: Ф. М. Достоєвський, М. В. Гоголь, міф про переписувача, міф про самозвания, міф про мрійника, житіє, образ-химера, петербурзька реальність.

Серед численних досліджень творчості Достоєвського проблема типології й характерології його героїв - не нова. Наукові студії від К.К. Істоміна i Л.П.Гроссмана до В.Г. Одинокова, В.М. Топорова, Г.К. Щеннікова, Т.О. Касаткіної, С.В. Бєлова, Р. Джакуїнти, Н.В. Самсонової і багатьох інших репрезентували дослідження цілого ряду героїв Достоєвського, серед яких значна увага приділялася герою-мрійнику. Зокрема Е.М. Жиляковою була запропонувала докладна класифікація мрійників Достоєвського. Дослідники В.Г. Одиноков, Р.Г. Назіров співвідносили тип мрійника 3 типом «підпільної людини», а в роботах Ф.В. Макаричева, Сін Мi Хе, С.О. Косякова зазначається, що «підпільна людина» і герой-ідеолог є своєрідними трансформаціями героямрійника. Значно менше уваги приділялося герою-переписувачу (М.Н. Епштейн, О.А. Горшечникова та ін.). Втім змушені зазначити, що проблема міфологізації героїв Достоєвського - як мрійника, так і двох інших переписувача i самозванця - не викликала активного зацікавлення в літературознавстві, чим і був обумовлений вибір нашого дослідження.

Мета статті - простежити формування міфів про «маленьку людину» за образом життя (мрійник, самозванець) i за родом занять (переписувач) в творчості раннього Достоєвського; визначити характерні особливості життя i поразки цих героїв в прагненні протистояти фантасмагоричності петербурзької дійсності. Під час дослідження були використані компаративний, культурно- 
історичний, соціально-психологічний методи.

Як відомо, образ «маленької людини» до російської літератури запровадив Пушкін. Гоголь в «Петербурзьких повістях» вніс свої доповнення до соціального портрету героя: це дрібний чиновник, «одвічний» титулярний радник, без будь-яких сподівань на покращення життя. Гоголівські герої, психологічні й побутові ситуації в їхньому житті настільки історично конкретизовані, що набувають характер універсально-узагальнених праобразів. Незважаючи на те, що вони були побудовані без допомоги міфологічної фантазії, їх можна розглядати в потрійному аспекті: де перше - індивідуальне, друге - соціально-типове i третє - міфо-символічне. Так створюються гоголівські міфи про самозванця, про мрійника, про переписувача, які разом 3 міфологізацією природної специфіки і фантасмагорією повсякденного буття $\epsilon$ складовими гоголівського літературного міфу про Петербург.

Молодий Достоєвський успадкував від Гоголя не тільки прагнення показати глибоку фантастичність реального життя столиці, а й його непомітного чиновника-переписувача. Слідом за гоголівським Башмачкіним виступають герої Достоєвського: Дєвушкін («Бідні люди»), Голядкін («Двійник»), Шумков («Слабке серце»). Всі вони, крім колезького реєстратора Шумкова - «одвічні» титулярні радники, основне заняття яких переписування. Ця єдина доступна для них форма діяльності стає способом реалізації їхньої особистості. Любов до переписування (у Шумкова найкращий почерк у Петербурзі), смирення поєднують їх iз Акакієм Акакієвичом i репрезентують сходження цих героїв до «архетипу писця як такого в світовій культурі» [5, с. 139]. У Гоголя міф про переписувача виступає як житіє, що проявляється в єдності святості й чудодійства. Відповідно 3 агіографічними канонами слідом за життєвим подвигом святого йдуть посмертні чудеса, які підтверджують його особливість. Посмертна помста Башмачкіна є чудом і в той же час протестом проти безглуздості свого існування в жорстокому світі.

В таких обставинах знаходяться й герої Достоєвського. Макар Дєвушкін тридцять років на службі займається переписуванням, так і не навчившись складати документи. Як і Башмачкін, він зневажає блага життя: обидва ходять у старому одязі, байдужі до їди, терплять численні глузування й зневагу від інших. Проте Достоєвський в зображенні свого героя пішов значно далі, переступивши межі житія. Бідність на рівні злиднів, відсутність освіти, одноманітна праця принижують людину, але не позбавляють іiі людяності. Чиновникам Достоєвського властиві взаєморозуміння і співчуття (Дєвушкін родина Горшкових, Шумков - Аркадій - родина Артем’євих). Вже не анекдотична шинель стає смислом життя героя, а скривджена сирота Варенька, в турботі про яку розкривається внутрішній світ Макара Дєвушкіна. Герой Достоєвського вже не може бути відлюдником в Петербурзі. Він замислюється над своїм життям, сподівається влаштувати особисте щастя. Але в тому й полягає специфіка Петербурга, що всі прагнення героя до нормального людського життя призводять його до поразки, а житійне начало «поступово перетворюється на свою протилежність, на антижитіє, тема якого - страшне моральне і містичне падіння» [5, с. 141]. Герой або божеволіє і назавжди 
віддаляється від міської метушні (Шумков), або створює свій світ, в якому ховається від дійсності і віддається мріям.

В фейлетонах «Петербурзького літопису», а також в «Хазяйці» і в «Білих ночах» Достоєвський розглядає мрійництво як «кошмар петербурзький» i «трагедію». В своєму усамітненні герой виступає в двох іпостасях: він чарівник, який може створити чаклунський світ забуття, i в той же час він невільник і жертва власної фантазії. Мрійник створює особливий ілюзорний світ із своїми пропорціями та законами, який, на відміну від реального Петербурга, дає йому простір і свободу.

В образі життя Василя Ординова («Хазяйка») і героя «Білих ночей» вгадуються, звичайно, в зниженому варіанті риси житійних моделей поведінки: уникання зовнішньої метушні, усамітнення, відсутність честолюбства. Герої живуть тихо i непомітно, як відлюдники, поки до їхнього усамітненого існування «не вдирається образ з петербурзького світського життя - образхимера», жінка» [1, с. 149]. Подальші спокуса і випробування, як способи перевірки на обраність і святість, герої не витримують. Врешті-решт, оповідь в обох творах є травестією житійних форм як таких.

В Петербурзі Достоєвського сподівання на нове життя, любов і щастя заздалегідь приречені на нездійсненність. Тема жінки, зливаючись із темою міста, обертається мотивом демонської спокуси, що веде героїв до катастрофи. Вихоплені зі свого замкнутого світу герої не переносять потрясіння: в Ординова починається психічний розлад, а до мрійника 3 «Білих ночей» приходить гірке протверезіння. Життя героїв, розпочате наче б то за матрицею житія, наприкінці твору більше нагадує антижитіє. Проте це цілком відповідає створеному письменником міфу про мрійника. На думку М.М. Дунаєва, кожний 3 мрійників Достоєвського «завжди сам по собі, кожний відокремлено, а всетаки всі вони єдині в своїй втечі від життя до примарної вигадки... і всі єдині в безрадісному підсумку свого життя» [3, с. 320].

Прагнення «маленької людини» протистояти петербурзькій дійсності породжує ще один міф - про самозванця. Пізніше В.Г. Короленко, досліджуючи суть самозванства, знаходив в ньому відбиття національної хвороби, яка відбувається від того, що душа людини «починає розгойдуватися, як маятник, між двома споконвічними полюсами російського життя, свавіллям, з одного боку, безправ'ям, з іншого» [4, с. 358-359].

Відчуття власної неповноцінності, прагнення здаватися іншим, ніж $\epsilon$ насправді, характеризує чиновника Голядкіна («Двійник»). Проїжджаючи в найманій кареті по Невському проспекту, він бачить свого начальника і не вітається 3 ним: мовляв, «я - це не я, а хтось інший, поважний» [2, с. 4]. Це й налаштовує на появу його двійника, самозванця, який легко досягає поблажливості начальства, чого не зумів зробити Голядкін-старший. Спритний двійник «обертається» так, що успіхи «оригінала» приписують йому, а всі негаразди оплачує ошелешений Голядкін-людина, який всерйоз запідозрив чаклунство. Фантасмагоричність петербурзької дійсності, в якій розгортається витіснення людини його самозванцем-двійником, дозволяє вірити більше в ірреальне, ніж у справжнє життя. 
Таким чином, всі варіанти протистояти петербурзькій реальності призводять героїв до катастрофи, що включає міфи про «маленьку людину» в більш загальний культурний міф про велике місто та його есхатологію.

\section{Література:}

1. Дилакторская О.Г. О «Шинели» Н.В. Гоголя // Литературная учеба, 1982. - № 3. - С. 149-154.

2. Достоевский Ф.М. Двойник. М.: Азбука - классика, 2010. - 256 с.

3. Дунаев М.M. Вера в горниле сомнений: Православие и русская литература в XVII-XX векаX. - М.: Издательский Совет Русской Православной Церкви, 2002. - 1056 с.

4. Короленко В.Г. Современная самозванщина. Бытовые очерки // Короленко В.Г. Полн. собр. соч. в 14 т. - СПб. : Изд-во т-ва А.Ф. Маркс, 1914. T. 3. - С. 271-368.

5. Эпштейн М.Н. О значении детали в структуре образа («Переписчики» у Гоголя и Достоевского) // Вопросы литературы, 1984. - № 12. - С. 134-145.

\section{References}

1. Dilaktorskaya, O. G. (1982). O «Shineli» N.V. Gogolya [About "The Overcoat" N.V. Gogol]. Literaturnaya ucheba - Literary studies. 3. 149-154 [in Russian].

2. Dostoevskiy, F. M. (2010). Dvoynik [Double]. Moskva: Azbuka - klassika [in Russian].

3. Dunaev, M. M. (2002). Vera v gornile somneniy: Pravoslavie i russkaya literatura v XVIIXX vekakh [Faith in the Crucible of Doubt: Orthodoxy and Russian Literature in the 17th-20th Centuries]. Moskva: Izdatel'skiy Sovet Russkoy Pravoslavnoy Tserkvi [in Russian].

4. Korolenko, V. G. (1914). Sovremennaya samozvanshchina. Bytovye ocherki [Modern imposture. Household sketches]. Polnoe sobranie sochineniy - Complete Works . Vols. 1- 14; Vol. 3. Sankt-Peterburg: Izdatel'stvo tovarishchestva A.F. Marks [in Russian].

5. Epshteyn, M. N. (1984). O znachenii detali v strukture obraza («Perepischiki» u Gogolya i Dostoevskogo) [On the meaning of detail in the structure of the image ("Scribes" by Gogol and Dostoevsky)]. Voprosy literatury - Literature issues. 12. 134-145 [in Russian].

The article considers one of the aspects of Gogol's influence on the work of the early F.M. Dostoevsky, that is the problem of mythologization of the "little man". The purpose of the study is to trace the formation of the myth of the scribe, the dreamer and the impostor in the works of F.M. Dostoevsky in the 1840s ("Poor People", "Double", "Weak Heart", "Mistress", "White Nights").The life of scribes and dreamers is studied according to a hagiographic plot, in which reality of St. Petersburg makes its allowances: life turns into anti-life, and heroes, instead of sainthood and miracles, face a moral and mystical fall. There is an intervention of the chimera image that is a woman who acts as a demonical temptation.

The myth of the impostor defines the desire of the hero to realize his ambitious fantasies, pretending to be someone else. But all the options to confront St. Petersburg reality lead the heroes to the catastrophe, which includes the myths of the "little man" in a more general cultural myth of the big city and its eschatology.

Key words: F.M. Dostoevsky, M.V. Gogol, the myth of the scribe, the myth of the imposter, the myth of the dreamer, the image of the chimera, the reality of St. Petersburg.

Стаття відправлена 12.11.2021 p.

(С) Тверітінова Т.И. 